\title{
Property Taxation of Leases and Other Limited Interests
}

Frank $M$. Keesling*

Leases, so-called "possessory interests" and other interests in property less than fee ownership, have given rise to a substantial amount of litigation involving the application of both property and income tax laws. Most of the cases have arisen in connection with property taxation and most of these in turn involve situations where private parties have held leases or other interests in so-called publicly owned property commonly exempt from taxation. These cases present two principal questions: (1) Notwithstanding the exemption of publicly owned property, are such privately held interests therein subject to taxation? (2) If so-and the answer has almost invariably been in the affirmative-how should the value of such interests be determined?

Several cases present the reverse situation, that is, the taxability of privately owned property leased to a public agency. They arise under State constitutional provisions granting or conditioning exemption from taxation upon the use of property for particular public purposes such as, for example, public school purposes. These cases suggest but do not squarely present the problem of whether the portion of the property represented by the value of the lease may be exempt from taxation as publicly owned property in all instances regardless of the particular public use made of the property.

Most of the pertinent income-tax cases lave involved copyrights and patents. They have been concerned with the question of whether transactions granting limited interests, such as motion picture rights, or publishing rights, or the right to use inventions for a period of time, should be regarded as hicenses to use the copyrights or patents which remain the property of the grantor, or as sales or transfers of interests in the property.

Although the income-tax questions are of substantial financial importance and involve the same basic principles as are involved in the propertytax cases, they cannot be discussed here. ${ }^{1}$ Instead, this discussion will be limited to a consideration of the problems arising out of the application of property-tax laws to leases and other possessory interests, a subject the importance of which has increased greatly as the result of the following circumstances and developments: (1) The increased use of publicly owned property for private purposes, particularly in connection with the performance of defense contracts for the federal government; (2) development of

* Member, Los Angeles Bar.

1 For a brief review of the cases, see Keesling, Conflicting Conceptions of Ownership in Taxation. 44 CALIF. L. REV. 866, 871 (1956). 
the practice of transferring title to property such as equipment and workin-progress to the federal government in the expectation of obtaining a property-tax exemption therefor; (3) recognition of the possibility that the leasing of property to a public agency may result in the exemption of a substantial portion of the value of the property; (4) the decision of the California Supreme Court in De Luz Homes, Inc. v. County of San Diego ${ }^{2}$ repudiating the time-honored rule which permitted a deduction of rent in the valuation of leases; and (5) recent decisions of the United States Supreme Court whicl suggest that where federally owned property is used for private purposes the entire value of the property may be subject to State and local taxation. ${ }^{3}$

An understanding of the problems presented requires an understanding of the nature and meaning of property and ownership. There are three basic views: (1) The indivisible theory, (2) the divisibility-of-property theory, and (3) the divisibility-of-ownership theory. ${ }^{4}$

According to the first view, property and ownership are identified with legal title and interests in perpetuity. They are conceived of as an indivisible, perpetual whole which must exist completely or not at all. Any interests less than complete ownership, such as those of a lessee or the right to use stories, plays or inventions for limited purposes, for limited periods, or in limited areas, are in the nature of privileges or hicenses emanating from a grant by the owner and they neither constitute property themselves nor give rise to ownership.

Although this view has been repudiated for property-tax purposes for a number of years ${ }^{5}$ and has inore recently been repudiated in the incometax treatment of receipts derived from the creation of limited interests in copyrights and patents, ${ }^{6}$ it is still widely held. In common understanding, the person named as the owner in a deed or bill of sale is considered the sole owner even though the property is in the possession of someone else pursuant to a lease or other instrument. For income-tax purposes leased property is generally considered as continuing to remain the property of the lessor and the rent is considered as mcome derived from the property rather than from a sale of an interest in the property. For sales- and use-tax purposes leases are generally not considered sales and the lessor is generally considered as using or consuming the property in the production of rent.

The second view, the divisibility-of-property theory, flatly denies that property and ownership are indivisible but insists instead that they consti-

245 Cal. 2d 546, 290 P.2d 544 (1955).

3 See text at note 34 infra.

4 For an extensive discussion of the various concepts as to the meaning of property and ownership, see Keesling, supra note 1.

5 See text at note 12 infra.

${ }^{6}$ See note 1 supra. 
tute an aggregate or bundle of separate rights, powers and privileges. An analogy is often drawn with a bundle of sticks. Just as the latter bundle may be broken down into its component elements, so the former may likewise be separated into its component rights, powers and privileges, which may in turn be distributed among various individuals. This view as to the nature of property and ownership was strongly advocated by Professor Hohfeld, among others, and is sometimes known as the Hohfeldian theory.

Of this view it may be said that it reaches the right answer for the wrong reasons. The right or privilege of using something in the world about us more or less exclusively, which is the essential characteristic of ownership, may, as this view recognizes, be shared or divided among a number of people in a number of different ways. Such a sharing or division occurs in the cases of joint tenancy, tenancies in common, and other forms of joint ownership. There is also a sharing or division in the case of corporations, provided we ignore the fictitious attribution of ownership to the corporate entity. There is likewise a sharing or division in the case of leases. Before the lease, the lessor has the exclusive right or privilege of using the property. By virtue of the lease the right or privilege of using during the period of the lease is transferred to the lessee and the lessor's right or privilege of using is confined to the period of time after the expiration of the lease. The transaction may be fairly and accurately described as resulting in a division between the lessor and the lessee of the right to use, and hence in a division of the essential element of ownership.

In these and other instances of divided interests, the land, buildings, story, play, invention or other things which are involved, are generally not divided. If these things were considered the property it would follow that there was no division of property. Possibly out of fear that this circumstance might invalidate the divisibility theory and might tend to confirm the indivisible theory of property and ownership, the proponents of the divisible theory categorically deny that the things which can be used and possessed, such as those mentioned, are property. Instead, they insist that property consists of the various rights, powers and privileges involved in ownership, which are divisible. Thus in the case of land, for instance, the property is not the land but instead consists of the various rights, powers and privileges the owner has with respect to the land. ${ }^{8}$

7 Hohfeld, Some Fundamental Legal Conceptions as Applied in Judicial Reasoning, 23 YaLe L.J. 16 (1913), reprinted in HoHreid, Fundaniental Legar Conceptrons (1923).

8 "Sometimes it [property] is employed to indicate the physical object to which various legal rights, privileges, etc., relate; .. . with far greater discrimination and accuracy-the word is used to denote the legal interest (or aggregate of legal relations) appertaining to such physical object." Hohfeld, supra note 7, at 21. (Emphasis added.) See also Eaton v. Boston C. \& M.R.R., 51 N.H. 504, 511, 12 Am. Rep. 147, 151 (1872): "In a strict legal sense, land is not 'property', but the subject of property. The tern 'property', although in common parlance 
Although it is frequently convenient to refer to rights, powers and privileges as property, this usage is not strictly accurate. Essentially ownership is a recognized relationship between individuals with respect to something which can be used or possessed more or less exclusively. The terms "rights," "powers" and "privileges," describe or denote various aspects of the relationship. Hence to refer to them as property confuses the relationship with the object of ownership. Furthermore, these terms are commonly employed to describe essentially similar relationships between individuals, such as the right to the custody of a child, or the right to a trial by jury, where there is neither ownership nor property involved. If rights, powers and privileges are not property in these other situations then they are likewise not property when they happen to relate to the various things which constitute the object of ownership.

The divisibility-of-ownership theory recognizes that the creation of limited interests, such as those resulting from the execution of a lease, does not result in a division of property. It by no means follows, however, that the record or title owner inust be considered as remaining the sole owner of the property. On the contrary, since the rights, powers and privileges with respect to the property are divided, it follows that the ownership of the property is also divided. Thus, in the case of a lease, since the lessor and the lessee both have interests in the property, they should be considered as joint or co-owners of the property.

PRIVATELY OWNED POSSESSORY INTERESTS IN PROPERTY THE TITLE TO WHICH IS PUBLICLY HELD

The constitutions of many, if not most of the States contain provisions for the exemption of property owned by the respective States or political subdivisions thereof. ${ }^{9}$ Although the federal constitution does not expressly so provide, until recently it was generally considered that property of the United States likewise was completely exempt from State or local taxation. ${ }^{10}$

frequently applied to a tract of land or a chattel, in its legal signification 'means only the rights of the owner in relation to it'. 'It denotes a right *** over a determinate thing'. 'Property is the right of any person to possess, use, enjoy, and dispose of a thing.' "

9 Thus CaI. Consx. art XIII, $\S 1$, provides: "... property ... such as may belong to this State, or to any county, city and county, or municipal corporation within this State shall be exempt from taxation, except such lands and the improvements thereon located outside of the county, city and county or municipal corporation owning the same as were subject to taxation at the time of the acquisition of the same by said county, city and county, or municipal corporation; provided, that no improvements of any character whatever constructed by any county, city and county or municipal corporation shall be subject to taxation."

$10 \mathrm{McCulloch}$ v. Maryland, 17 U.S. (4 Wheat.) 316 (1819); Van Brocklin v. Tennessee, 117 U.S. 151 (1886); Wisconsin Cent. R.R. v. Price County, 133 U.S. 496 (1890). 
Nevertheless, it is firmly established, and has been for a great many years, that privately held possessory interests, such as those created by lease, in so-called publicly owned property are subject to tax notwithstanding the exemption of publicly owned property. ${ }^{11}$ In support of a different conclusion it lias been urged that leaseholds and other possessory interests are not property; that property is an indivisible entity and any interests less than fee ownership inust of necessity be regarded as amounting to nothing more than a license or privilege originating in and existing by virtue of the consent or indulgence of the owner. ${ }^{12}$

In rejecting this argument and in upholding the tax on possessory interests in publicly owned property the courts have repudiated the indivisible theory of property and ownership for property-tax purposes and liave instead adopted either the divisible-property theory or the divisible-ownership theory. Which of these two has been adopted is not clear from the cases. As a practical matter it makes little difference which theory is followed since it is eminently clear that under either, the value of privately held possessory interests should not be exempt simply because the remainder interest is publicly owned and exempt from tax. This conclusion is particularly easy to reach if the possessory interests themselves are considered to be property. Thus, to illustrate, the City of Los Angeles leases tidelands for

11 The cases involve a number of different types of limited interests which may be classified as follows:

(a) Ordinary leases pursuant to which the tenant has the right for a period of time to the use or possession of the property to which title is publicly beld. Trimble v. City of Seattle, 231 U.S. 683 (1914) ; Maricopa County v. Fox Riverside Theatre Corp., 57 Ariz. 407, 114 P.2d 245 (1941); Texas Co. v. County of Los Angeles, 52 Cal. 2d 54, 338 P.2d 440 (1959); El Toro Dev. Co. v. County of Orange, 45 Cal.2d 586, 290 P.2d 569 (1955); Victor Valley Housing Corp. v. County of San Bernardino, 45 Cal.2d 580, 290 P.2d 565 (1955); Fairfield Gardens, Inc. v. County of Solano, 45 Cal. 2d 575, 290 P.2d 562 (1955); De Luz Homes, Inc. v. County of San Diego, 45 Cal. 2d 546, 290 P.2d 544 (1955); Blinn Lumber Co. v. County of Los Angeles, 216 Cal. 468, 14 P.2d 512 (1932); San Pedro R.R. v. Los Angeles, 180 Cal. 18, 179 Pac. 393 (1919), reversing 167 Cal. 425, 139 Pac. 1071 (1914); Hanımond Lumber Co. v. County of Los Angeles, 104 Cal. App. 235, 285 Pac. 896 (1930); Greene Lime Terminal Co. v. Martin, 122 W. Va. 483, 10 S.E.2d 901 (1940); Otter Tail Power Co. v. Degnan, 64 N.D. 413, 252 N.W. 619 (1934); Moeller v. Gormley, 44 Wash. 465, 87 Pac. 507 (1906).

(b) So-called oil or mineral leases pursuant to which the holder may enter upon the property to explore for and remove oil and other minerals. Graciosa Oil Co. v. County of Santa Barbara, 155 Cal. 140, 99 Pac. 483 (1909); California v. Moore, 12 Cal. 56 (1859).

(c) The rights of contractors to enter upon and use property the title to which is publicly held in the course of the performance of a government contract. United States v. County of Allegheny, 322 U.S. 174 (1944); Kaiser Co. v. Reid, 30 Cal.2d 610, 184 P.2d 879 (1947); Douglas Aircraft Co. v. Byram, 57 Cal. App. 2d 311, 134 P.2d 15 (1943).

(d) The interest of a squatter who has settled upon government owned land, made improvements and has the right to possession of the land as against everyone except the owner. People v. Shearer, 30 Cal. 645 (1866).

12 The argument is made in one form or ancther in virtually all of the cases dealing with the subject. See cases cited note 11 supra, particularly San Pedro R.R. v. Los Angeles and Kaiser Co. v. Reid. 
a number of years to an individual or company. If the lessee's interests are property, then it follows that the City has transferred some of its property and only the remaining property, that is, the right to collect the consideration for the transfer and the right to the use and possession of the land after the expiration of the lease, is exempt as publicly owned property. The rights and powers of the tenant for the duration of the lease, being property and being privately owned, are taxable to the same extent as any other privately owned property.

Under the divisible-ownership theory the same results should be obtained but the reasoning is somewhat different. According to this view, the interests-that is, the rights, powers and privileges-both those retained by the City and those transferred to the tenant, although relating to property are not themselves property. The property is the land. Since the City retains some interest in the land it might properly be said to be an owner, and hence the land might be described as being publicly owned. In view of the interests of the tenant, however, it cannot be said that the property is completely publicly owned any more than it can be said to be completely privately owned. The sensible solution is to hold that the jointly owned properly is both exempt and taxable in proportion to the values of the respective interests.

As a matter of fundamental legal theory, there should be no distinction between real property and personal property with respect to the taxation of possessory interests. Although the California Supreme Court, in General Dynamics Corp. v. County of Los Angeles, ${ }^{13}$ held invalid a tax on privately held possessory interests in personal property owned by the Umited States, it did not do so on the grounds that there is any basic difference between real property and personal property in this respect. On the contrary, the court expressly noted that under the California constitution the legislature is authorized not only to provide for the taxation of all forms of tangible personal property but also for any legal or equitable interest therein. The court further pointed out, however, that historically a distinction has been drawn in the California law between real property and personal property with respect to the taxation of possessory interests. Since the admission of the State to the Union in 1850, the California law has expressly provided for taxing the possession, or the right to the possession, of real property. No such provisions have been made with respect to personal property. This omission, the court concluded, "reflects not merely a lack of detail, but a consistent pattern of taxing tangible personal property as an entity or not at all."14 It is abundantly clear from the opinion of the court that the legislature could correct this omission and provide for the taxation of privately 
held possessory interests in publicly owned personal property and possibly could go even further and, for reasons which will be discussed later, ${ }^{15}$ subject the person in possession to a tax on the full value of such property, including the value of the publicly held remainder interest as well as the value of the privately held possessory interest.

Where all the interests in property are privately held it is the common practice to assess the entire property as a unit to the holder of the record title or the owner of the remainder or fee interest. Thus, where one individual leases land to another, it is not the practice to value the different interests and to assess each party on the values of their respective interests. Instead, the entire property, including the value of the lessee's interest, is assessed to the lessor. Why, it has been urged, should a different practice be followed and the value of the leasehold or other possessory interest be separately determined and taxed where the title to the property is held by a public body?

In answer to the argument the courts have pointed out that where all the interests are privately held, there is no need to incur the administrative trouble and expense involved in treating each interest as a separate iten of property to be separately valued and assessed. In such a case, the more convenient practice of making one assessment of the entire property may appropriately be followed, since such assessment will reflect the aggregate value of all the interests and all of such interests are subject to tax. If, however, privately held interests in governinent property themselves constitute property subject to taxation, such interests must be separately valued and assessed, for otherwise they would escape taxation completely. ${ }^{10}$

It is seriously questionable whether the practice of assessing the entire property as a unit to the owner of the remainder interest should be followed in all cases even though all of the interests are privately owned and fully subject to tax. The practice is certainly convenient, particularly in the case of real property with respect to which public records of title owners are maintained, and reheves already over-burdened taxing officials of the necessity of ascertaining the existence of possessory interests and valuing and assessing them separately from the remainder interests. In most instances the practice operates with reasonable fairness. In the case of an ordinary lease, for instance, the lessor, knowing that the entire property may continue to be assessed to him as a unit, may take that circumstance into account in fixing the terms of the lease. Thus he may require

15 See text at note 51 , infra.

16 See San Pedro R.R. v. Los Angeles, 180 Cal. 18, 179 Pac. 393 (1919), reversing 167 Cal. 425, 139 Pac. 1071 (1914), in which the point is considered and discussed at some length. See also Hammond Lumber Co. v. County of Los Angeles, 104 Cal. App. 235, 285 Pac. 896 (1930); De Luz Homes, Inc. v. County of San Diego, 45 Cal. 2d 546, 290 P.2d 544 (1955). 
the payment of additional rental to compensate for the taxes, or he may require the tenant, as is commonly done, to pay a portion or all of the taxes.

There are, however, instances where the practice may result in substantial inequities. Generally speaking, such instances arise where the value of the remainder interest is relatively small in proportion to the total value of the property and the owner of such interest has no opportunity to work out an arrangement with the owner of the possessory interest for the payment of a portion or all of the taxes. For example, an individual owning land of an assessable value of, say, $\$ 100,000$, leaves a life estate to his widow and the remainder interest to his son. The life expectancy of the owner of the life estate is such that the life estate has a value of $\$ 80,000$ and the remainder a value of $\$ 20,000$. Under the rule of convenience, the annual taxes on the entire assessable value of $\$ 100,000$ would be assessed to the son. Although there may be no personal liability for the tax, as is generally the rule in the case of real-property taxes, in order to avoid the loss of his remainder interest which would result from a sale of the property for non-payment of taxes, the son is forced to pay a tax computed not only on the value of his own interest but also on the value of someone else's interest which is much larger.

The problem becomes even more acute in the case of personal-property taxes where there is personal liability. The practice of leasing machinery, equipment and other types of personal property for financing and tax reasons is growing by leaps and bounds. Such leases are often for long periods of years and frequently provide for much larger rental payments in the earlier years than in the later years. In the case of a lease for a 10year period, of property worth $\$ 12,000$, the rental payments in the first 3 years may be $\$ 4,000$ per year and thereafter may be reduced sharply to fairly nominal amounts. Thus parties engaged in the business of making such leases, or their heirs or assignees, may find themselves in the position of owning remainder interests the value of which is relatively small in proportion to the total value of the property. If the taxes on the entire property are assessed against the owner of the remainder interest, such owner will be personally liable for taxes computed on the value of possessory interests owned by other parties, the aggregate value of which may be many times the value of the taxpayer's interests. In extreme cases the tax itself might equal or exceed the value of the interests owned by the taxpayer.

It may be that no particular sympathy should be felt for the lessor, either because such transactions are commonly motivated by tax-avoidance purposes or because liability for property taxes is a known incident of such leasing transactions. A different situation exists when the remainder interests are transferred to other parties by gift, inheritance, sale or in 
satisfaction of debts owing to creditors. Suppose an individual, either by inheritance or in satisfaction of a debt, acquires a remainder interest in personal property subject to long-term leases providing for nominal rental payments. The property, assessed as a unit, including the value of the possessory interests, has an aggregate assessable value of $\$ 1,000,000$, the annual tax on which, at a 6 per cent rate, amounts to $\$ 60,000$. The fair market value of the remainder interests acquired is only $\$ 20,000$. Thus by acquiring the remainder interest the individual becomes personally liable for a tax the amount of which for 1 year alone is three times the value of the interests acquired.

It is utterly impractical to require the separate valuation of the various interests in property, either real or personal, and the separate assessment of such interests to the owners thereof in all cases. In the case of real property, the prevailing practice of assessing the property as a unit to the titleor remainder-owner should be continued. In addition to the existing exception of separately valuing possessory interests and assessing them to the owner thereof where the title to the property is publicly held, an exception should also be made, and the possessory interests should be separately valued and assessed, upon application of the title-owner and upon a showing that the failure to make such a separate assessment of the possessory interests will result in substantial inequity.

In the case of personal property, with the possible exception of instances where some of the interests are publicly owned and exempt from tax and others are privately owned and subject to tax, the property should be valued and assessed as a unit in all cases. Instead, however, of the prevailing practice of assessing such property to the owner of the remainder interest, it would be fairer, and just as practical, to assess the property to the person in possession. An exception should be made in the case of property in the possession of someone who has no right to use and hence no ownership interest in the property, such as a warehouseman or a repairman who has property belonging to others in his possession for the purpose of making repairs or alterations. An exception should also be made in cases where the possessory interest is of short duration, such as a day, a week or month. In such cases the practice of assessing the property as a unit to the owner or to the owner of the remainder interest should be continued. Where, however, the possessory interest has existed or may continue for an indefinite or substantial period of time, as in the case of a lease from year to year or for a term of years, the property should be assessed as a unit to the person in possession rather than to the owner of the remainder interest. As a practical matter, it is probably just as easy, if not easier, to ascertain the person in possession as it is to ascertain the owner of the remainder interest. Since property taxes are an annual affair, there 
is a certain element of appropriateness in requiring the person who has the use of the property throughout the year to bear the burden of the annual tax. Such a result is commonly achieved by contract between the parties, a practice which tends to confirm the reasonableness of the proposed rule. Such a practice should also facilitate or assure the collection of personal property taxes in many instances. If the assessment is made to the owner of the remainder imterests, such as the lessor in the case of a lease, and if such person does not reside in the jurisdiction and does not have an office, place of business or other property there, as is often the case, the tax will be uncollectible if the property is destroyed, sold or removed from the jurisdiction. On the other hand, if the assessment is made to the person in possession and if he resides in the jurisdiction or has other assets there, as is commonly the case where property is leased for business purposes, the tax would still be collectible.

Under California law the assessor is directed to assess all taxable property to "the persons owning, claiming, possessing, or controlling it ...." Where the remainder and possessory interests in property are separately owned, as in the case of property leased, this provision seems clearly to give the assessor a choice of taxpayers. Thus he could, if he saw fit to do so, assess the person in possession rather than the owner of the remainder interest. The existence of such a choice seems anomalous when it is considered that personal-property taxes often amount to substantial sums and constitute a personal liability of the assessee. The law should be revised to eliminate the choice and to provide for assessment of personalproperty taxes only to the person in possession, except in the cases indicated.

\section{II}

\section{PUBLICLY OWNED POSSESSORY INTERESTS IN PROPERTY THE TITLE TO} WHICH IS PRTVATELY HELD

Not uncommonly, privately owned property, such as land and office buildings, is leased to the United States, the States or subdivisions thereof for various public purposes. When this occurs, is the entire property taxable? Or is the value of the portion represented by the leasehold interest exempt as publicly owned property? No cases have been found involving the problem where exemption is conditioned solely upon public ownership. In view of the well-established rule that possessory interests in property are themselves either property or an interest in property, the answer to the foregoing questions is clear. If, as the cases hold, a privately owned leasehold interest in publicly owned property is taxable as privately owned property, then it logically follows that a publicly owned leasehold interest 
in privately owned property is exempt as publicly owned property. If the tax is levied on the entire property without diminution for the value of the lease, a portion of the tax is applicable to the value of the lease and hence to that extent is invalid as a tax on publicly owned property.

In support of a different conclusion it may be urged that in cases where the rental payable under a lease is fair, the value of the right to receive the rent added to the value of the remainder interest should approximately equal the value of the entire property; consequently the execution of a lease to a public agency for a fair rental does not result in any reduction in the value of privately owned property and accordingly should not result in any reduction in the assessed value of property for tax purposes.

Although the point is eminently sound as a matter of policy, it is inconsistent with the generally prevailing practice of assessing property taxes on the basis of gross values without any deduction for debts, including obligations incurred to acquire the property assessed. ${ }^{18}$ As a corollary of this practice, it is necessary, in order to avoid a false duplication of property values, to exempt the seller from taxation on the value of the claim for the purchase price. ${ }^{19}$ To illustrate: $A$ is the owner of property of a value of $\$ 100,000$ which he sells to $B$ for that amount. $B$ makes no downpayment but agrees to pay the entire consideration in installments over a period of years. Notwithstanding that $B$ acquires no equity in the property, he is subject to assessment on the basis of its entire value without any deduction for the obligation incurred to acquire it. In order to avoid an obvious duplication of values, $A$ is exempt from tax on the value of his claim against $B$.

If, in the foregoing example, $A$ had sold his property on the same terms to a public agency, $A$ would still be exempt from taxation on the value of his claim notwithstanding the fact that the property transferred is exempt as publicly owned property. Thus, even though the transaction does not result in any reduction in the aggregate value of privately owned property, it does result in a reduction in assessed values for property-tax purposes.

Consistency requires that similar results be obtained in the case of leases and other limited interests. If a lease is to be treated as an interest in property, then the rent payable as a condition of acquiring the interest should be treated as the purchase price of the interest. Hence in the case of a lease from a public agency no deduction should be allowed for the

18 This is the general rule in California. An exception is made in the taxation of solvent credits against which it is possible to offset debts owing to bona fide residents of the State. CAT. REv. \& TAX CODE $\$ 1060$.

19 CAx. ConsT. art. XIII, $\S 1$, provides that "a mortgage, deed of trust, contract, or other obligation by which a debt is secured when land is pledged as security for the payment thereof, together with the money represented by such debt, shall not be considered property subject to taxation." Notes and bonds are exempt. CaI. REv. \& TAX CodE \$212. Accounts receivable are subject to tax but at extremely low rates. CaI. Const. art. XIII, \& 14; CaL. REv. \& TAx. CODE § 2153. 
rental obligation in computing the value of the lease. Conversely, where privately owned property is leased to a public agency, the claim for the rent payable should not be included in valuing the property and the assessment should be based only on the value of the remainder interest.

Even though it is recognized that a publicly owned lease in property, the remainder interest in which is privately held, is itself publicly owned property, it may, nevertheless, be urged that a tax assessed to the lessor, based on the entire value of the property including the value of the lease, should be valid if neither the public body nor its property is held accountable for the tax. As will be discussed later, a similar argument has been sustained by the United States Supreme Court in upholding State taxes assessed to persons in possession of property of the United States. ${ }^{20}$ Where, however, publicly owned property is specifically and unqualifiedly exempt from taxation, it seems clear that the value thereof cannot be included in the computation of a tax even though the tax is assessed to a private person and even though the public agency or its property is not held liable for the tax.

The California constitution provides that "property used exclusively for public schools, and such as may belong to this State, or to any county, city and county, or municipal corporation within this State, shall be exempt from taxation."21 The exemption is clear, unambiguous and unqualified. It would seem, therefore, that the property mentioned is completely exempt regardless of how and to whom the tax is assessed and regardless of whether the public agencies mentioned and their property are or are not held accountable for the tax.

Any doubts on this score are completely set at rest by the decision of the California Supreme Court in Ross v. City of Long Beach, ${ }^{22}$ involving the exemption of property used exclusively for public schools. Privately owned property was leased to a public school district and used exclusively for scliool purposes. The court held that the exemption of property used exclusively for public schools is clear and unambiguous and admits of no exceptions, and, accordingly, the value of such property cannot be included in the computation of an assessment to the lessor.

The exemption of property belonging to the State or its political subdivisions is equally clear, unambiguous and unqualified. It should follow, therefore, that the value of such property likewise cannot be included in the computation of property-tax assessments, regardless of whether such assessments are levied against private persons as in the Ross case, or directly against the State or its political subdivisions. 
Although under certain limited circumstances property of the United States may be subjected to State and local taxation, the tax must not discriminate against the United States or its property. ${ }^{23}$ Accordingly, if, in the case of a lease to the State or its political subdivisions, the value of the lease may not be included in the computation of an assessment against the lessor, avoidance of discrimination requires a similar result in the case of leases to the United States.

\section{III}

\section{VALUATION OF LIMITED INTERESTS}

Where, as in the case of a lease, the ownership of property is divided between a remainder and a present interest, the aggregate value of the respective interests should approximately equal the value of the entire property. Accordingly, where one of the interests is publicly owned and exempt from tax and the other is privately owned and subject to tax, one method of determining the value of the taxable interest is to (1) determine the value of the entire property in the same manner that would normally be employed if the entire property were subject to tax and (2) apportion the value so determined between the respective interests.

The apportionment can be made quite simply by the use of actuarial tables. When the present or lessee's interest expires, the owner of the remainder interest will be the owner of the entire property free and clear of the lease. Accordingly, the present value of the remainder interest should be an amount equal to the present value of the right to receive at the expiration of the lease a sum equal to the value of the entire property. The value of the present or lessee's interest is the difference between the value of the entire property and the value of the remainder interest so computed.

For example: $A$ is the owner of land which, on the valuation date, is leased to the State of California for a period of 10 years. In accordance with usual and accepted methods of valuation, the entire property is determined to have a value of $\$ 100,000$. Assuning that 6 percent is a reasonable rate of return, according to actuarial tables, the right to receive $\$ 1.00$ ten years from now has a present value of $\$ .54$. Accordingly, the present value of $A$ 's remainder interest is $\$ 54,000(\$ 100,000 \times .54)$. This figure represents the portion of the total value of the property which is subject to tax as privately owned property. The difference of $\$ 46,000$ between this figure and the total value of the property $(\$ 100,000-\$ 54,000)$ represents the value of the lease which is exempt from tax as State-owned property.

In the case of depreciable property an adjustment must be made since 
such property is generally considered to decline in value due to use. Hence in making the apportionment the depreciated value of the property at the expiration of the present or lessee's interest should be employed in lieu of the total value of the entire property as in the case of land. To illustrate: A building of a total value of $\$ 100,000$ has an estimated remaining life of 20 years. It is leased to the State of California for 10 years. At the expiration of the lease, half of the building's useful life will presumably be exhausted and accordingly the building will have a remaining value at that time of only $\$ 50,000$. Thus the present value of the remainder interest is only $\$ 27,000$, or half as much as in the case of land of equal present value. This figure represents the portion of the total value which is subject to tax as privately owned property, and the $\$ 73,000$ difference between this figure and the total value of the building represents the value of the lease which is exempt from tax as publicly owned property.

Under the foregoing method of apportionment, the same values are assigned to the respective interests regardless of whether there is any rent payable and regardless of whether the rent, if any, is either excessive or inadequate. This result may be objected to on the grounds that to the lessor rent is income from the property, the right to receive which is a valuable incident of ownership which should be taken into account in determining the value of the lessor's property. Conversely, it may be urged that to the lessee the obligation to pay rent is a burden which reduces the value of the lease and consequently should be taken into account in determining its value.

These objections are consistent with the view which identifies property with the fee, or legal, title. According to this conception of ownership, the lessor remains the sole owner of the property. In leasing the property lie is, in effect, simply using it for the production of income. If the rental is a fair rental, the value of the property to the lessor is unaffected. In such a case the existence of a lease neither adds to nor detracts from the value of the property and hence there is no remaining value to be attributed to the lease. If the rental is excessive as of the valuation date, the property will have a greater value on that account than it would otherwise have, and as a result, the lease, in effect, has a minus value. If the rental is inadequate, the value of the property to the lessor is decreased and in such a case some value may be assigned to the lease. Where the rental is inadequate the lessee presumably could find someone who wonld take over the lease, assume the obligation to pay rent, and pay a bonus or premium to the lessee for the assigninent.

As noted previously, ${ }^{24}$ property-tax laws generally contemplate that property should be assessed on the basis of its full value without any 
deduction for the unpaid portion, if any, of the purchase price or other indebtedness of the owner. As a corollary, claims for the unpaid portion of the purchase price are generally exempt from taxation. If leases are to be treated as property, or as an interest in property, consistency requires similar treatment of unpaid rent. Thus, claims for the unpaid rent should not be taken into account to augment the value of the remainder or lessor's interest on the one hand, and should likewise not be taken into account to reduce the value of the lease or the lessee's interest on the other.

The proper method to be employed in the valuation of possessory interests in property was discussed at some length in Hammond Lumber Co. v. County of Los Angeles. ${ }^{25}$ The case involved the assessment of the possessory interest of a company in tidelands acquired by lease from the City of Los Angeles. In arriving at the assessed value of the possessory interest, the assessor employed what is sometimes referred to as the capitalization-of-net-income method. This method involves estimating the amount of net income to be produced by the property over the period of the lease and then determining the present value of the right to receive such income. In making the determination, the assessor allowed a deduction for the rent to be paid under the terms of the lease. The court, after holding that the possessory interest was property subject to taxation, notwithstanding that the title to the land was publicly owned, commented with approval upon the method of valuation employed. In the course of its opinion, it both referred to and quoted from several texts dealing with the valuation of leaseholds which also approved the method employed. ${ }^{28}$

This method may be a proper method for ascertaining the so-called bonus or equity value of the lease, that is, the amount which an assignee might be willing to pay to the lessee for an assignment of the lease and in addition assume the rental obligations under the lease. It is not an appropriate method for determining the fair market value of the possessory interest since, for the reasons heretofore expressed, no deduction should be allowed in arriving at such value for the unpaid balance of the rent or purchase price of the possessory interest. Thus the method should have been rejected, not because it produced too high a value, as contended by the taxpayer in the Hammond Lumber Co. case, but because it produced too low a value.

The valuation of possessory interests was also considered in Blinn Lumber Co. v. County of Los Angeles. ${ }^{27}$ This case, like the Hammond Lumber Co. case, involved the assessment of a possessory interest in

26 See McMrceaex, Long and Short Term Leasemolds 90, 91 (2d ed. 1921); Zangerle, Princtples of Rear Estate Appratsing 31 (1924). 
property leased from the City of Los Angeles. The assessment complained of was arrived at by a very intricate procedure which is difficult, if not impossible, to understand. Although the court quite properly rejected it, in the course of its opinion the court emphatically re-stated with approval the view expressed in the Hammond Lumber Co. case to the effect that in arriving at the value of the possessory interest the amount of rent to be paid should be subtracted as an expense.

Furthermore, the court indicated that in the case of improvements made by a lessee a deduction should be made for amortization over the period of the lease. Such a deduction is eminently proper for income-tax purposes, but it is highly improper for property-tax purposes. The purpose of such a deduction for income-tax purposes is to permit the recovery tax free of the capital investment represented by the cost of the property. In contrast with the income tax, the property tax is essentially a tax measured by capital. The allowance of such a deduction for property-tax purposes would have the effect of deducting, and thereby exempting, a part of the measure. Hence the reason for allowing the deduction for income-tax purposes serves also as the reason for not allowing the deduction for property-tax purposes.

In De Luz Homes, Inc. v. County of San Diego, ${ }^{28}$ the supreme court again considered the proper method to be followed in the valuation of leases, and, in an outstandingly able and comprehensive opinion by Mr. Justice Traynor, sharply reversed its former views as to the proper treatment of both rent and amortization of improvements made by lessees. Rent was held not deductible for the reason urged above that it should be considered as the cost or purchase price of the interest being valued. The court likewise held that no deduction should be allowed for amortization of improvements made by a lessee for the reason that such a deduction would result in deducting a part of the answer which the valuation process is designed to achieve. In the words of Mr. Justice Traynor, "Rent paid for a leasehold interest, like the cost of improvements that revert to the lessor, is part of the cost or purchase price of the leasehold, and to include a deduction for it, is likewise to include an item of expense based on the answer, i.e., the value of the property."29

\section{IV}

\section{CLASSTFICATION OF LIMITED INTERESTS AS REAL OR PERSONAI PROPERTY}

Following the decision in the De Luz case, the Califormia Legislature added section 107.1 to the California Revenue and Taxation Code, provid-

2845 Cal. 2d 546, 290 P.2d 544 (1955).

29 Id. at 567, 290 P.2d at 558. See also Texas Co. v. County of Los Angeles, 52 Cal. 2d 54, 338 P.2d 440 (1959) in which the Court emphatically reiterates the view that rent should be considered as the purchase price of obtaining a leasehold interest and should not be deducted in valuing the interest. 
ing, in effect, that the rule of the case disallowing a deduction for rent in the valuation of leases should be followed prospectively only and should not be applied in the valuation of leases created prior to the date of the decision in the $D e$ Luz case. The policy of the legislature in this respect is eminently fair, particularly when it is considered that prior to the De Luz case the practice of allowing a deduction for rent in the valuation of leases had been followed from time immemorial and, furthermore, had been specifically approved by the appellate courts of the State, including the supreme court. It is seriously questionable, however, whether the legislature has the constitutional authority to limit the application of the De Luz case to leases executed thereafter.

The Iegislature has broad powers with respect to the classification and exemption of personal property from taxation. ${ }^{30}$ I.t has no similar powers with respect to real property. Hence the validity of the amendment turns on whether the interest of a lessee in real property is real property or personal property. The counsel to the California Legislature has expressed the opimon that a lease of real property is a chattel real; that a chattel real is personal property, and hence the legislature could validly exempt leases of real property from taxation, wholly or in part. ${ }^{31}$ The Attorney General of California is of the opimion that a lease of real property is, itself, real property and that the legislature was without authority to provide that leases entered into before the decision in the De Luz case should be valued or taxed differently than leases entered into thereafter. ${ }^{32}$

The conclusion that an interest in real property is personal property rather than real property is contrary to the commonly accepted notion that a portion of something is of the same character or nature as the whole. It is also inconsistent with all of the various views as to the nature of property and ownership.

According to the indivisible theory, the interest of a lessee of real property is not itself property but instead is something in the nature of a license, and lence the question as to the classification of the interest as real or personal property does not arise.

According to the divisible theory, property consists of the various rights, powers, privileges or interests involved in ownership. In the case of a lease of land, the principal difference between the interests of the lessor and the lessee is temporal in character. Thus during the existence of a lease, the lessee has possession of the land, and, subject to varying restrictions, may use it more or less as he sees fit, in much the same manner as he

30 CAL. Const. art. XIII, $\S 14$.

31 Opinion of Legislative Counsel to Assemblyman Vincent Ttromas, May 19, 1958, 3 CCH State TAX Rep. (CAI.) $\mathbb{2}$ 201-212.

3231 Ops. Cax. ATI'y Gen. 17 (1958). 
could if he were the sole owner. The lessor has similar rights commencing with the expiration of the lease and continuing indefinitely thereafter. In view of the similarity between the respective interests, it seems clear that whatever classification is accorded the interests of one must likewise be accorded the interests of the other. Thus if the interest of the lessor is considered real property, the interest of the lessee must likewise be classified as real property.

According to the divisible-ownership theory the lessor and the lessee are joint or co-owners of the property leased. Again it seems abundantly clear that their interests are alike insofar as the classification of real or personal property is concerned.

\section{V}

STATE AND LOCAL TAXATION OF PROPERTY OF THE UNITED STATES

Since $M c$ Cullough v. Maryland ${ }^{33}$ it has been axiomatic that property of the United States is completely immune from State and local property taxes. The taxation of a lessee from the United States based only on the value of the lessee's interest is not inconsistent therewith since the lessee's interest is privately owned property, the taxation of which does not resnlt in imposing a tax either on the United States or upon its property. ${ }^{34}$

In 1958 the United States Suprenie Court, in a series of three cases involving use and property tax laws of the State of Michigan, announced an important exception to the doctrine of immunity of federal property from State and local taxation. The court held that persons in possession of property of the United States pursuant to lease or other contractual arrangements with the United States, were subject to State and local taxation based not only on the value of their possessory interests but on the value of the entire property including the value of the federally owned remainder interests. The power of taxation in such cases is subject to the following restrictions, among others: (1) The tax nust be a liability of the persons in possession and not a liability of the United States; (2) the property of the United States may not be subject to seizure and sale for non-payment of the tax; and (3) there nuust be no discrimination against the property of the United States.

The first two of the series of three cases, United States v. City of Detroit ${ }^{36}$ and United States $v$. Township of Muskegan, ${ }^{36}$ involved a statute of the State of Michigan providing that lessees and users of tax-exempt real property should be subject to taxation on the entire value of the property to the same extent and in the same manner as if they were the 
owners of the property with the exception that the taxes should be assessed against the lessees and users personally and should not be a lien on the taxexempt property leased or used. ${ }^{37}$ The validity of the statute was challenged on the grounds that "it should be treated as nothing but a contrivance to lay a tax on"38 tax-exempt property. The court upheld the tax on the grounds that it was in the nature of a use tax rather than a tax on the property, thus implying that if it had been designated as a tax on the property it might have been invalid.

In referring to the argument challenging the validity of the tax, the court states:

We do not find this argument persuasive. A tax for the beneficial use of property, as distinguished from a tax on the property itself, has long been a commonplace in this country.... In measuring such a use tax it seems neither irregular nor extravagant to resort to the value of the property used; indeed no more so than measuring a sales tax by the value of the property sold. ${ }^{39}$

In City of Detroit v. Murray Corp. of Americu, ${ }^{40}$ the third of the series of three cases dealing with use- and property-tax laws of the State of Michigan, the taxes involved were designated as property taxes and were assessed to a subcontractor based upon the value of materials and work-inprogress in its possession, title to which was held by the Umited States. The validity of the taxes was challenged on the grounds that they infringed the immunity of property of the federal government from State and local taxation.

The majority of the court upheld the taxes and in doing so emphasized the fact that they were imposed on a private party and that there was no effort to hold the United States or its property accountable.

In the course of its opimion the court quoted from Lawrence v. State Tax Comm'n:" "We are concerned only with its practical operation, not its definition or the precise form of descriptive words which may be applied to it." 42 The court held that in their practical operation and effect the taxes in question were identical to those upheld in the preceding two cases, and stated: "We see no essential difference so far as constitutional tax immunity is concerned between taxing a person for using property he possesses and taxing him for possessing property he uses when in both instances he uses the property for his own private ends." $\$ 3$

376 Mich. STaT. ANN. \& 7.7(5)-(6) (Supp. 1957).

38 United States v. City of Detroit, 355 U.S. 466, 470 (1958).

39 Ibid. (Eniphasis added.)

40355 U.S. 489 (1958).

41286 U.S. 276, 280 (1931).

42 City of Detroit v. Murray Corp. of America, 355 U.S. 489, 492 (1958).

43 Id. at 493. 
The fact that the particular taxing statutes involved did not expressly state that the person in possession is taxed for the privilege of using or possessing personal property was disposed of as follows:

To strike down a tax on the possessor because of such verbal omission would only prove a victory for empty formalisms. And empty formalisms are too shadowy a basis for invalidating State tax laws.... In the circumstances of this case the State could obviate such grounds for validity by merely adding a few words to its statutes. Yet their operation and practical effect would remain precisely the same. ${ }^{44}$

It seems abundantly clear, therefore, that, notwithstanding the momentary implication to the contrary in the first two cases, where property of the United States is used by private parties the entire value of the property may be included in the assessment of a tax against such private parties, even though the tax is designated as a property tax and even though the statute imposing it does not specifically state that the tax is imposed for the privilege of using or possessing the property.

The imposition of a tax on persons using government property based on the entire value of the property may be objected to on the grounds that it results in taxing one person on the value of property belonging to another and hence is invalid for the same reasons that it is generally considered invalid to tax one person based on the income of another. ${ }^{45}$ Curiously enough, the argument does not appear to have been made or commented upon in either the majority or dissenting opinions in any of the three cases.

In refutation of the argument it may be observed that where the interests in property are divided, as in the case of a lease, and all the interests are taxable, it is now and has been for many years the common practice to assess the entire property, including the value of the possessory interest, to the owner of the fee or remainder interest. Since leases or other possessory imterests are property or an interest in property, this practice clearly results im taxing one person upon the value of the property of another. If this practice is valid, and virtually all property-tax laws are predicated on the assumption that it is, then it should be equally valid to reverse this procedure and assess the entire property, including the value of the remainder interest, to the owner of the possessory interest. In fact, since property taxes recur annually, it seems somewhat more fitting and appropriate that the current tax should be assessed to the person who currently has the right to the possession, use and enjoyment of the property rather than to the owner of the remainder interest whose possession, use and enjoyment of the property may not commence until some distant or

45 Hoeper v. Tax Comm'n of Wis., 284 U.S. 206 (1931), reversing 202 Wis. 493, 233 N.W. 100 (1930). 
indefinite date in the future. As previously noted, ${ }^{46}$ it is a common practice to provide in leases that the lessee shall pay the current taxes. In view of this practice, a rule of law providing for the assessment of the current taxes to the lessee can scarcely be said to be arbitrary or capricious.

The statute involved in the first two of the series of three cases dealing with the Michigan law authorized the assessment of a tax only to lessees and users of exempt property. In the third case, dealing with the personalproperty tax of Michigan, the court strongly implies that the tax would be valid only if assessed to a person who not only has possession of federally owned property but also the right to use such property for his own ends. ${ }^{47}$ It seems abundantly clear, therefore, that a State or local tax assessed to a person who has the naked possession only of federally owned property, such as a warehouseman, garageman or repairman, would not be valid.

Although the point is not mentioned in any of the opinions in the three cases, it would also seem clear that to support the tax the right to use must be more or less exclusive. Thus it would not be permissible to assess a person with a tax on the value of a Post Office or other government building simply because he, as a member of the general public, has the right to use the property on the local tax date.

It likewise seems reasonable to conclude that the right to use should be of some substantial duration. Surely it would be arbitrary and capricious to assess the entire amount of an annual tax based on the entire value of property to a person who has possession of and the right to use the property for only a brief period of time, such as an hour, a day or a week. For income-tax purposes, a person in the tax jurisdiction for other than temporary purposes may be subjected to a tax based on his entire world-wide income, but such a tax cannot be validly assessed against a person who is only temporarily present in the jurisdiction as a visitor. ${ }^{48} \mathrm{~A}$ similar rule should be adopted for property-tax purposes, both in the assessment of possessory interests as property and also in the assessment of persons having the right to use property based upon the entire value of the property used.99

Thus instead of three, there are in effect six conditions which must be observed if the entire value of property, the remainder interest in which is owned by the United States, is to be taken into account in assessing State and local taxes: 
1. The tax may not be a liability of the United States but must be a liability of some private person.

2. The tax may not be collected through seizure and sale of the government property.

3. The tax must be non-discriminatory.

4. The person assessed must have the right to use for his own ends as distinguished from bare possession only.

5. The right to use must be more or less exclusive and not simply a right to use shared with the general public. time.

6. The right to use nust exist for some substantial period of

The right to use something more or less exclusively is an essential characteristic of ownership. Thus, to say that a person is an owner is simply another way of saying that he has the exclusive right to use, either presently or at some definite or indefinite time in the future. Conversely, to say that a person has the exclusive right to use property is synonymous with stating that he has an ownership interest in the property. ${ }^{50}$ If a tax based on the entire value of property, the remainder interest in which is federally owned, unust comply with the foregoing six conditions, then in view of the last three conditions, the tax is conditioned on the existence of a right to use on the part of the assessee in the nature of an ownership interest. It follows that even though the tax is labelled a use tax it is essentially an ad valorem property tax because, like a property $\operatorname{tax},(1)$ it is computed according to the value of property, and (2) it is assessable only to persons who have an ownership interest in the property assessed. This conclusion is reinforced if the tax is assessed annually, as of a given tax date, and otherwise has the earmarks of the familiar property tax.

The various situations with respect to the division of interests in property and the assessinent of taxes according to the value of part or all of the property fall into one or the other of the following five categories:

1. A person owns all the interests and is assessed a tax based on the value of the entire property.

2. A person owns the remainder interest only and is likewise assessed a tax based on the value of the entire property including the value of leases or other possessory interests not owned by him.

3. A person is the owner of the remainder interest only and is assessed a tax based on the value of such interest, either because the law provides for separate assessment of the various interests in all cases, or because the possessory interest is publicly owned and is exempt froin tax. 
4. A person owns the possessory interest only and is assessed a tax based upon the value of the possessory interest, either because the law provides for the separate assessment of the various interests in all cases, or because the remainder interest is publicly owned and exempt froin tax.

5. A person is the owner of a possessory interest consisting of the right to use property more or less exclusively for his own purposes for a substantial period of time, and is assessed a tax based upon the value of the entire property including the value of the remainder interest.

In all five cases the tax is computed according to the value of a portion or all of the property and in all cases is assessed to a person who has an ownership interest in the property. In view of the similarities, the classification accorded the tax in any one case should be accorded the taxes in the remaining categories. In the first four cases the tax would commonly be considered an ad valorem property tax. Therefore the tax in the fifth case is likewise an ad valorem property tax, regardless of how labelled-whether as a use tax, a tax on the possession of property, or otherwise.

It may well be that in some of the states the existing taxing provisions are so worded as to authorize the imposition of a tax on lessees or others using property of the United States based upon the total value of the property. In other states such a result may possibly be obtained relatively simply through the adoption of provisions similar to those in Michigan. The situation in California in this respect is quite complex and far from clear.

The status of the California law may be summarized briefly as follows:

1. Privately held possessory interests in tangible personal property, the title to which is publicly held, are not subject to separate assessment as such; the legislature may, by a simple majority, amend the law and provide for such separate assessment.

2. The owners of possessory interests in tangible personal property, title to which is held by the United States, are subject to assessment based upon the value of the entire property, including the value of both the possessory and remainder interests; if this conclusion is in error for the reasons hereinafter discussed, then, short of an amendment to the California constitution, there is nothing the legislature can do to provide for such assessment.

3. Privately held possessory interests in real property, the title to which is publicly held, are subject to separate assessment; the owners of such possessory interests may not be subjected to a tax based upon the full value of the property including the value of the 
remainder interests; short of a constitutional amendment, the legislature cannot validly provide for the assessment of the entire value of the property to the owner of the possessory interests.

It may seem anomalous indeed that the holder of a possessory interest in personal property, the title to which is in the United States, may not be taxed on the value of his possessory interest separately, but may be taxed based upon the total value of the property including not only the value of his possessory interest but also the value of the remainder interest not owned by him. Yet this seems to be the status of the existing law.

In General Dynamics Corp. v. County of Los Angeles, ${ }^{51}$ the California Supreme Court clearly held that although a possessory interest in personal property is itself property subject to taxation, the legislature has failed to provide for the separate assessment of possessory interests im personal property. Thus, as the court stated, tangible personal property must either be taxed "as an entity or not at all."152 The fact that the quoted statement is in the alternative clearly leaves open the door to the possibility that the entire interest in property may be taxed even though a limited interest therein may not be separately valued and assessed.

California Revenue and Taxation Code Section 405 requires the assessment of all taxable property "to the persons owning, claiming, possessing or controlling it at 12:00 o'clock meridian of the first Monday in March." Assessment of the entire property to the holder of the possessory interest seems clearly authorized as an assessment to a person "possessing" or "controlling" the property.

Under the California constitution, property owned by the United States, unlike property owned by the State or political subdivisions thereof, is not unconditionally exempt from tax. Instead, the exemption accorded federally owned property is limited to such property as is "exempt under the laws of the United States."153 Since property of the United States used by private parties for their own ends is not exempt from State or local taxation under the laws of the United States, it is likewise not exempt under the Califorma constitution. Therefore such property is taxable property within the meaning of California Revenue and Taxation Code Section 405 , and the entire value thereof should be assessed to the holders of possessory interests therein.

In the Murray case, ${ }^{53 a}$ a private contractor had possession of, and the right to use for his own ends, tangible personal property, title to which was in the United States. Pursuant to local law authorizing the assessment of property to the person in possession, the contractor was assessed

5151 Cal. 2d 59, 330 P.2d 794 (1958).

62 Id. at 64, 330 P.2d at 797.

83 CaI. Const. art. XIII, § 1.

53a See note 40 supra. 
a tax, designated as a property tax, based on the value of the entire property. Neither the United States nor its property was held accountable for the tax. The tax was held valid.

A private contractor in California has the possession of, and the right to use for his own ends, tangible personal property, title to which is in the United States. Pursuant to local law (California Revenue and Taxation Code Section 405), authorizing the assessment of property to the person in possession, the contractor is assessed a tax designated as a property tax, based on the value of the entire property. No effort is made to hold either the United States or its property accountable for the tax. Since the circumstances are the same as in the Murray case, the answer should likewise be the same. Hence the tax should be valid.

It may be urged that all of the conditions for taxing federally owned property are not met for the reason, among others, that California Revenue and Taxation Code Section 2914 purports to authorize the seizure and sale for non-payment of personal property taxes of all of the personal property assessed to the assessee, including the property in which the United States has an interest; that such a provision is invalid and therefore the assessment is invalid. The statement with respect to the provisions of California Revenue and Taxation Code Section 2914 is correct, but the conclusion that the assessment is invalid by no means follows. Other valid renedies for the collection of the tax, such as the seizure and sale of other personal property of the assessee ${ }^{54}$ or instituting of a suit against the assessee, ${ }^{65}$ are provided for by this and other sections of the code. Therefore, the inability to seize and sell the particular property assessed in which the United States has an interest does not defeat the assessment. The fact that the code is invalid in purporting to authorize the seizure and sale of property in which the United States has an interest should have no bearing on the validity of the assessment and should not prevent the local tax officials from collecting the tax through lawful means which do not interfere with the United States or its property. The situation in this respect is the same as in the Murray case where a tax based on the value of property of the United States was held valid notwithstanding the existence of general provisions, not availed of in the particular case, authorizing the seizure and sale of the property assessed.

A more serious objection to the assessment of personal property in

54 CAx. REv. \& TAX. CoDE $\$ 2914$ provides as follows: "Taxes due on unsecured property may be collected by seizure and sale of any of the following property belonging or assessed to the assessee:

(a) Personal property.

(b) Improvements.

(c) Possessory interests." (Emphasis added.)

so Cac. Rev. \& Tax. Code $\$ 3003$. 
which the United States has an interest may be made on the ground that such an assessment is discriminatory against federally owned property since, under the California constitution, as previously noted, ${ }^{56}$ it is not possible to assess personal property in which the State or political subdivisions thereof have an interest. It is probable, lowever, that there is only an insignificant amount of personal property belonging to the State and political subdivisions thereof being used by private persons and hence there is no discrimination in fact. Before striking down a tax assessed against contractors and others having substantial amounts of property of the United States in their possession on the grounds that the tax is discriminatory, the courts should require proof of actual and substantial discrimination.

If this conclusion is wrong, and if the courts should hold that theoretical or potential discrimination is sufficient to invalidate the tax based upon the value of property in which the United States has an interest, or if a convincing case of actual discrimination sliould be made and the tax is invalidated for that reason, then it would seem that, short of an amendment to the California constitution modifying the exemption accorded property belonging to the State or political subdivisions thereof, there is nothing the State can do to insure collection of a tax based upon the value of personal property in the possession of contractors and others dealing with the United States.

It may be suggested, of course, that the legislature might adopt a use tax applicable not only to persons using property of the United States but also to persons using property of the State and its political subdivisions. There are several objections to this suggestion. In the first place, if the tax meets the six conditions previously mentioned ${ }^{57}$ in order to apply to the use of property of the United States, the tax, instead of being a use tax, would in effect be identical with an ad valorem property tax. ${ }^{58}$ As such it would still be invalid as applied to the personal property, if any, of the State or political subdivisions thereof in the possession of private persons. Even if the tax could be so devised as not to be completely identical in its practical operation and effect with a property tax, the California courts, because of the specific constitutional exemption of property belonging to the State and its political subdivisions, may well hold the tax invalid as a contrivance to lay a tax on exempt property.

If the legislature, through the device of a use tax, can validly impose a tax based on the value of property belonging to the State or its political subdivisions which is used for private purposes, then it would seem to 
follow that the legislature could likewise impose a tax based on the value of all other exempt property which is privately used. Thus the legislature could, for all practical purposes, nullify the constitutional exemption of non-profit educational institutions of college grade, ${ }^{69}$ churches, ${ }^{00}$ orphanages, ${ }^{01}$ veterans, ${ }^{62}$ householders ${ }^{03}$ and others too numerous to mention.

It should be observed in this connection that the immunity of property of the United States from State and local taxation, to the extent that it is immune, is not attributable to provisions in either the Constitution or laws of the United States expressly exempting such property. Rather, it is attributable to judicial interpretation of the Constitution as forbidding the States and their political subdivisions from hampering or interfering with the functioning of the federal government. ${ }^{04}$ The assessment of the United States directly or the seizure and sale of property of the United States for the collection of a State tax would hinder the functioning of the federal government and hence has been, and still is, forbidden. Where neither the United States nor its property is held accountable for the tax, the taxation of property of the United States to persons using it does not, in the opinion of the majority of the United States Supreme Court, constitute a sufficiently serious interference with the functioming of the federal government as to be prohibited. Thus in the cases dealing with the tax laws of Michigan, the court was free to uphold the taxes there considered. If, however, either the Constitution or the laws of the United States had contained specific provisions expressly and unqualifiedly exempting property of the United States from State and local taxation in plain terms similar to those in the California constitution relating to the exemption of property, it is probable that the Michigan taxes-those designated as use taxes as well as those designated as property taxes-would have been held invalid.

Even if the foregoing hurdles could be overcome and a valid use tax devised applicable to the use of property belonging to the State and its political subdivisions as well as to property belonging to the United States, there is still the problem of complying with the requirements of article XI, section 12 of the California constitution which prohibits the legislature from imposing taxes for county, city, town or other municipal purposes. One method of complying with the requirements of this section is to provide that the tax should be administered centrally and that the revenues be used

69 CaI. Const. art. XIII, $\S 1 \mathrm{a}$.

60 CaI. Const. art. XIII, $\$ 11 / 2$.

61 CAI. Const. art. XIII, \$1 1/2a.

62 CAL. Const. art. XIII, $\S 11 / 4$.

63 Cat. Const. art. XIII, $\S 101 / 2$.

64 See cases cited note 10, supra.

65 See text at note 40 , suspra. 
for State, as distinguished from local, purposes. Such a solution would result in substantial duplication of assessments and collection procedures, would deprive the local governments of the revenue from a source wlich, in an economic sense at least, is a property tax, and would also give rise to a problem of fixing the rate of the State use tax so as to be comparable to the rates of local property taxes which vary from locality to locality and from year to year.

Another method of compliance which is specifically contemplated by the section $^{68}$ is for the legislature to authorize the counties and other political subdivisions to impose use taxes. If a use tax is to be adopted in an effort to overcome the discrimination obstacle, it is believed that this method is the one which should be followed. If this method were adopted the tax could be administered by local taxing officials, the revenues could be used for local purposes, and the rate could be fixed locally and adjusted from time to time so as always to be equal to the local personal property tax rate.

Unlike the situation with respect to personal property, it is abundantly clear that privately held possessory interests in real property, the title to which is in the name of the State, its political subdivisions, or the United States, may be separately assessed and taxed according to the value of such interests. It seems equally clear that the assessments must be limited to the value of such possessory interests and that the value of the publicly held remainder interests may not be included. Under existing law, taxes on real property, as distinguished from taxes on personal property, may be collected only througli sale of the property assessed. Since property in which the United States has an interest may not be sold for the payment of State or local taxes, it follows that even though the taxes were assessed they could not be collected. The legislature could, of course, amend the law to provide for personal liability of the assessee for real property taxes but there would still be the problem of discrimination arising from the fact that under the California constitution property belonging to the State or its political subdivisions may not be subjected to ad valorem taxation. Unlike the situation which probably exists with respect to personal property, there unquestionably is a substantial amount of property owned by the State or its political subdivisions being used by private persons pursuant to lease or other arrangements. Hence, in the case of real property the problem of discrimination is actual and real and not just a possibility, as in the case of personal property. Any effort to solve the discrimination problem through the adoption of a use tax will encounter 
the same difficulties as mentioned above in connection with the similar problem relating to personal property.

Short of an amendment to the California constitution dealing comprehensively with the problem, it would seem (1) that the local assessors should rely upon existing statutory provisions for the assessment of contractors and others using personal property of the United States for their own ends, based upon the entire value of such property, and (2) that possessory interests in real property, the title to which is publicly held, should continue to be assessed on the value of such interests and no effort be made to include the value of the publicly owned remainder interests. 